\title{
Evaluation of the role of the brand and symbol of Red Crescent Society of the Islamic Republic in the effectiveness of incidents and crises of the country (case study of East Azarbaijan)
}

\author{
Ebrahim Halajian*, Seyyed Ali Nabavi, Behzad Ferdosian
}

Department of Management, Islamic Azad University, Branch of Sari, Sari, Iran

Received: 10 February 2015

Accepted: 07 March 2015

*Correspondence:

Dr. Ebrahim Halajian,

E-mail: navabshamspour@gmail.com

Copyright: (C) the author(s), publisher and licensee Medip Academy. This is an open-access article distributed under the terms of the Creative Commons Attribution Non-Commercial License, which permits unrestricted non-commercial use, distribution, and reproduction in any medium, provided the original work is properly cited.

\section{ABSTRACT}

Background: The main question of this study was that what is the relation between national creditability of the brand and symbol the Red Crescent and the effectiveness of this brand and symbol on 1) The social assistance, 2) the social works 3) Encouraging people to assist 4) The successes of the operations of executive managements in times of disasters and crises?

Methods: This investigation was conducted as a case study and a dedicated study in relation to the earthquake in East Azerbaijan Province that happened in 2013, the study population included 3500 people among donors and volunteer for aid working who collaborated with the Red Crescent Society in the earthquake relief. The sample size of research was estimated 346 people according to the Cochran formula with 5\% probability of error and a structured questionnaire was the tool of data collection.

Results: The influence of the name and brand of the Red Crescent Society of the Islamic Republic is moderate and significant in social assistance in social work in people's willingness to assist and in the success of the operations of executive managers in times of disasters and crises.

Conclusion: In the earthquake in Azarbayejan influence of the name and brand of the Red Crescent Society of the Islamic Republic is affective in social assistance in social work in people's willingness to assist and in the success of the operations of executive managers in times of disasters and crises.

Keywords: Brand and symbol of Red Crescent Society, Incidents and crises

\section{INTRODUCTION}

Iran, according to the United Nations Development Programme, is considered as one of the 10 accident-full countries in the world at the beginning of 2005. According to the report, Iran in the last ten years, has suffered from the highest number of people who were killed annually due to earthquake in the world. ${ }^{1,2}$

Lessons from the disasters that occurred in the past, have shown that almost immediately after the incidence of each crisis, the first response for rescuing the injured and trapped people, is seen by volunteer people with strong incentives but without the necessary training in this field and without regard to their health and personal safety. Although such measures may lead to save some lives but in most cases, the actions of such paramedics, cause serious injuries and numerous problems. The main purpose of the search and rescue is to optimize operations and minimize the causalities caused by it. ${ }^{3-5}$

To achieve these goals, the search and rescue networks peruse three pillars of vulnerability assessment, 
specifying comprehensive facilities to deal with the risk and a balance between vulnerability and facilities for coping with causalities. Planning and organization in the search and rescue in the accidents should be done according to the initial estimated needs. Organizations without a basic understanding of the effects of disasters, the immediate needs of the affected area, the status quo capacities and local or regional response to event, attempt to send or provide grant aids, however probably they send aids which are unnecessary, inappropriate, and lead to rework for local authorities to apply them for survivors. ${ }^{6-8}$

To avoid the difficulties resulted in trying to do this kind of arbitrariness in accidents, disasters and crises, the efforts must be pre-programmed with salient practice. The decision making to perform a rescue operation should be based on the two following factors: 1) Regarding all status quo risks and 2) Doing the best for the greatest possible number of affected people ${ }^{9}$ and planning and making necessary coordination in order to avoid overlapping of responsibilities and carrying out parallel and iterative works in the field of search and rescue, preparing required guidelines for preparation in the search and rescue according to the country's policies, planning for provision of equipment needed to temporary housing, nutrition and health of victims, planning the initial estimation of losses and damages, planning for special required education for related organizations involved in the search and rescue, planning to supply equipment and facilities for the search and rescue, planning for the identification of non- state domestic and foreign aids and acquiring the aids in these crises, support, coordination and monitor the performance of specialized working groups and the search and rescue of provinces, are of tasks which can be considered for the purposes of search and rescue. ${ }^{10-12}$

Nevertheless, due to the nature of the issue and the input question which was stated at the beginning of the statement of the problem section and also due the recent responsibility of the Red Crescent Society and the Red Cross, as the custodian of the country's search and rescue and since in fact, this is a charitable NGO organization that during its 90-year history, from the first day until now, has been active in all crises and has done a lot of efforts in the relief and rescue and these efforts include the services related to some sections of the society, such as the search and rescue organization and using a variety of theoretical and practical knowledge and technical capabilities of individuals and the system as the main organ responsible for the search and rescue in the country, ${ }^{13}$ what is its role and credit in order to affect the management of disasters and crisis?

So far, no research has been conducted on the evaluation of the role of the brand and symbol of Red Crescent of the Islamic Republic on the effectiveness of crisis management. So the main question of this study was how and to what extent is the national credit of the brand of Red Crescent and the effectiveness of this brand and sign on 1) The social assistance, 2) The social works 3) Encouraging people to assist 4) The successes of the operations of executive managers as the main entity which are custodians of rescue and relief in times of disasters and crises?

\section{METHODS}

The recent research in terms of research design is descriptive (non-experimental) and the descriptive and survey method was used. This research in terms of objective is an applied research and its purpose is to develop the practical knowledge of the Red Crescent in time of the accidents. This study in terms of the nature of the data is among the surveys where the quantitative data is obtained from the questionnaire and the data is used for data analysis. In general, the population of the study includes all persons who according to information taken by the Red Crescent, helped victims of unpredicted accidents such as floods, earthquakes, fires, landslides and granted people's aids to the Red Crescent Society of the Islamic Republic of Iran.

Based on existed information and statistics, 3,500 prominent and well-known donors of the country in the field of accidents and crises are included that in this study, 3500 donors who actively participated in the earthquake of East Azerbaijan, were studied. Since studying the total population in the scientific research is not possible due to facing with the time, cost and manpower limitations, therefore, by using random sampling, only a part of the subjects is going to be studied. Since the size of the population of the study is 3,500 people of donors and volunteer paramedics who also worked with the Red Crescent and their information is recorded and available, they also helped victims in West Azerbaijan earthquake or were present in the region.

According to Cochran formula, the sample size in this study was estimated 346 people with a $5 \%$ probability of error. After the formation of the theoretical framework and raising hypotheses and the theoretical model, the questionnaire are developed considering the size of and representatives of the research. The questionnaire includes questions that every 10 questions assess one of the 4 items that presented in the survey questions. In this study the Cronbach's alpha is used to estimate the reliability coefficient.

The Cronbach's alpha coefficient is known as one of reliability or trustworthiness coefficients. Investigating 30 questionnaires in form of pre-test and calculating the Cronbach's alpha coefficient which was 0.75 , the reliability of the study questions is confirmed. The t-test was used to assess the normal distribution of data and according to data normality, the parametric tests were used. The one-sample t-test was used to evaluate hypotheses. 


\section{RESULTS}

Between the 346 respondents to the questionnaire, there were 251 men and 95 women. Namely men with the percentage of 72.5 , more than women, answered to the questions. According to this fact that in the statistical population of the Red Crescent donors, the number of men was greater than women, this is evident in the sample and the number of respondents. This means that most of the respondents (144 respondents) who constitute $41.5 \%$ of the total are between the ages of 31 to 40 years. The respondents with ages 41 to 50 with a frequency of 109 (31.5 percent) are in the next level. Of the 346 respondents, most of respondents with a frequency of 185 and $30.1 \%$ of the total, were educated (Associates' degree - bachelors' degree - MA) and 3 others have not mentioned their education. Also in the second rank, there are respondents with education (illiterate, primary, middle and secondary) with a frequency of 104 people. Most respondents (37 percent) didn't mention their income. The frequencies indicate that there were 90 respondents with incomes between 500 thousand to a million, the lowest frequency is related to the 13 respondents who have announced their income over two million Tomans.

Table 1: Description of the main variables of the research.

\begin{tabular}{|lllll|}
\hline Items & No. & Min & Max & Mean \pm SD \\
\hline $\begin{array}{l}\text { Social } \\
\text { assistance }\end{array}$ & 346 & 10 & 50 & $\begin{array}{l}32.45 \pm \\
10.4\end{array}$ \\
\hline Social works & 346 & 10 & 50 & $\begin{array}{l}30.43 \pm \\
12.3\end{array}$ \\
\hline $\begin{array}{l}\text { The executive } \\
\text { managements in }\end{array}$ & & & & \\
times of & 346 & 10 & 50 & $37.87 \pm$ \\
disasters and & & & & 13.6 \\
crises & & & & \\
\hline $\begin{array}{l}\text { Encouraging } \\
\text { people to assist }\end{array}$ & 346 & 10 & 50 & $33.56 \pm$ \\
\hline
\end{tabular}

The Table 1 above shows that the mean score of the successes of the executive managements in times of disasters and crises are the most and the mean score of social works is the least.

Table 2: The Kolmogorov Smirnov test for assessing normality of the respondents' views.

\section{Total}

\begin{tabular}{|lll|}
\hline No. & & 346 \\
\hline The & Mean \pm & $165.67 \pm$ \\
normal & SD & 21.7 \\
\cline { 2 - 3 } parameter & Negative & -0.0118 \\
\hline K-S value & & 1.22 \\
\hline Significance & & 0.0102 \\
\hline
\end{tabular}

Based on the above tables in terms of the distribution of the scores of the subjects, the various descriptive indices show that the distribution of the sample is normal or quasi- normal. Because a significant probability of 0.102 is greater than 0.05 , thus, assumption of normal distribution of the data is accepted. Furthermore, according to the obtained indices and according to the scales of predictor variables and the criterion is interval and therefore the collected data is quantitative. Meanwhile, based on the central limit theorem, it can be concluded that the data distribution tends to the normal distribution. So in order to test the research hypotheses it is possible to use parametric tests.

In this section with respect to the raised hypotheses in this study and also considering the measurement scale of desired variables, the one-sample t-test was used.

\section{The first hypothesis}

The role of the brand and the symbol of the Red Crescent of the Islamic Republic are significant in the social assistance of the country's accidents and crises.

Table 3: Role of the brand and the symbol of the Red Crescent of the Islamic Republic in the social assistance.

\begin{tabular}{|lccllll|}
\hline Item & $\mathbf{t}$ & df & $\begin{array}{l}\text { Signific- } \\
\text { ance }\end{array}$ & $\begin{array}{l}\text { Mean } \\
\text { differe } \\
\text {-nce }\end{array}$ & \multicolumn{2}{l|}{$\begin{array}{l}\text { Confidence } \\
\text { Interval }\end{array}$} \\
\hline $\begin{array}{l}\text { Social } \\
\text { assista }\end{array}$ & 36.6 & 1.6 & 0.005 & 24.73 & 32 & Low \\
-nce & & & & & & \\
\hline
\end{tabular}

Given that the probability of significance value $(0.005)$ is less than the significance level (0.05), with a probability of 95 percent, the null hypothesis is rejected. In other words the impact of the brand and symbol of the Red Crescent of Islamic Republic on the social assistance in the times of disasters and crises is in a significant level of impact and higher then middle level and given the table of the summary of descriptive statistics, we see that the obtained mean is 32.46 and the theoretical mean is about 30 .

\section{The second hypothesis}


The role of the brand and the symbol of the Red Crescent of the Islamic Republic is significant in the social works of the country's accidents and crises.

Table 4: The role of the brand and the symbol of the Red Crescent of the Islamic Republic in the social works.

\begin{tabular}{|lccllll|}
\hline Item & $\mathbf{t}$ & df & $\begin{array}{l}\text { Signific- } \\
\text { ance }\end{array}$ & $\begin{array}{l}\text { Mean } \\
\text { differe } \\
\text {-nce }\end{array}$ & \multicolumn{2}{l}{$\begin{array}{l}\text { Confidence } \\
\text { Interval }\end{array}$} \\
\hline $\begin{array}{l}\text { Social } \\
\text { work }\end{array}$ & 0.56 & 1.6 & 0.023 & 16.16 & 23.8 & Low \\
\hline
\end{tabular}

Given that the probability of significance value $(0.000)$ is less than the significance level (0.05), with a probability of 95 percent, the null hypothesis is rejected. In other words the impact of the brand and symbol of the Red Crescent of Islamic Republic on the social works in the times of disasters and crises is in a significant level of impact and higher then middle level and given the table of the summary of descriptive statistics, we see that the obtained mean is 30.43 and the theoretical mean is about 30 .

\section{The third hypothesis}

The role of the brand and the symbol of the Red Crescent of the Islamic Republic is significant for encouraging people to assist in the country's accidents and crises.

Table 5: The role of the brand and the symbol of the Red Crescent of the Islamic Republic for encouraging people to assist.

\begin{tabular}{|lccllll|}
\hline Item & $\mathbf{t}$ & df & $\begin{array}{l}\text { Signific- } \\
\text { ance }\end{array}$ & $\begin{array}{l}\text { Mean } \\
\text { differe } \\
\text {-nce }\end{array}$ & \multicolumn{2}{l|}{$\begin{array}{l}\text { Confidence } \\
\text { Interval }\end{array}$} \\
\hline $\begin{array}{l}\text { Encour } \\
\text {-aging } \\
\text { people } \\
\text { to assist }\end{array}$ & 55.8 & 106 & 0.000 & 47.45 & Low \\
\hline
\end{tabular}

Given that the probability of significance value $(0.000)$ is less than the significance level $(0.05)$, with a probability of 95 percent, the null hypothesis is rejected. In other words the impact of the brand and symbol of the Red Crescent of Islamic Republic to encourage people to assist in the times of disasters and crises is in a significant level of impact and higher then middle level and given the table of the summary of descriptive statistics, we see that the obtained mean is 33.56 and the theoretical mean is about 30 .

\section{The fourth hypothesis}

The role of the brand and the symbol of the Red Crescent of the Islamic Republic is significant in the successes of the operations of executive managements in times of disasters and crises.

Table 6: The role of the brand and the symbol of the Red Crescent of the Islamic Republic in the successes of the operations of executive managements in times of disasters and crises.

\begin{tabular}{|lllllll|}
\hline Item & $\mathbf{t}$ & df & $\begin{array}{l}\text { Signifi } \\
\text {-cance }\end{array}$ & $\begin{array}{l}\text { Mean } \\
\text { differ- } \\
\text { ence }\end{array}$ & \multicolumn{2}{l|}{$\begin{array}{l}\text { Confidence } \\
\text { Interval }\end{array}$} \\
\hline $\begin{array}{l}\text { Successes of } \\
\text { the operations } \\
\text { of executive } \\
\text { managements }\end{array}$ & 19.3 & 106 & 0.000 & 21.496 & 14.23 & 27.89 \\
$\begin{array}{l}\text { in times of } \\
\text { disasters and } \\
\text { crises }\end{array}$ & & & & & & \\
\hline
\end{tabular}

Given that the probability of significance value $(0.000)$ is less than the significance level $(0.05)$, with a probability of 95 percent, the null hypothesis is rejected. In other words, the impact of the brand and symbol of the Red Crescent of Islamic Republic in the successes of the operations of executive managements in times of disasters and crises is in a significant level of impact and higher then middle level and given the table of the summary of descriptive statistics, we see that the obtained mean is 37.87 and the theoretical mean is about 30 .

\section{DISCUSSION}

The study showed that the impact of the brand and symbol of the Red Crescent of Islamic Republic in the social works, the social assistance, for encouraging people to assist and in the successes of the operations of executive managements in times of disasters and crises, is middle and significant.

\section{The first hypothesis}

The role of the brand and the symbol of the Red Crescent of the Islamic Republic is significant in the social assistance of the country's accidents and crises. In other words the impact of the brand and symbol of the Red Crescent of Islamic Republic on the social assistance in the times of disasters and crises is in a significant level of impact and higher then middle level and given the table of the summary of descriptive statistics, we see that the obtained mean is 32.46 and the theoretical mean is about 30 . The results of the present study are consistent with the study of Aghamiri et al. (2013). Given the results of this study, it seems that in sum, the efficiency of the Red Crescent Society due to the immense scope of the incident, especially about the distribution of the required items between people and also health care services, was very good. ${ }^{14}$

\section{The second hypothesis}


The role of the brand and the symbol of the Red Crescent of the Islamic Republic is significant in the social works of the country's accidents and crises. In other words the impact of the brand and symbol of the Red Crescent of Islamic Republic on the social works in the times of disasters and crises is in a significant level of impact and higher then middle level and given the table of the summary of descriptive statistics, we see that the obtained mean is 30.43 and the theoretical mean is about 30. The results of the present study are consistent with the study of Aghamiri et al. (2013).

\section{The third hypothesis}

The role of the brand and the symbol of the Red Crescent of the Islamic Republic is significant for encouraging people to assist in the country's accidents and crises. In other words the impact of the brand and symbol of the Red Crescent of Islamic Republic to encourage people to assist in the times of disasters and crises is in a significant level of impact and higher then middle level and given the table of the summary of descriptive statistics, we see that the obtained mean is 33.56 and the theoretical mean is about 30 . The results of the present are consistent with the study of Esfandiar (2013) which investigates the voluntary activities in the Red Crescent.

Undoubtedly promoting the volunteering culture in the world and pandemic existence of volunteers without financial and material expectations and merely on the basis of pure human nature that God has deposited in humans, can have a significant effect on all facets of society especially in economic and social areas. So it seems that the participation of volunteers in society and promotion of culture of volunteering, in addition to facilitating the countries' access to development, can revitalize the human's pure values in different countries. Moreover, responsibility of volunteers for community can be a revival of human values and beliefs and lead communities to the growth and excellence.

\section{The fourth hypothesis}

The role of the brand and the symbol of the Red Crescent of the Islamic Republic is significant in the successes of the operations of executive managements in times of disasters and crises. In other words, the impact of the brand and symbol of the Red Crescent of Islamic Republic in the successes of the operations of executive managements in times of disasters and crises is in a significant level of impact and higher then middle level and given the table of the summary of descriptive statistics, we see that the obtained mean is 37.87 and the theoretical mean is about 30 . The results of the present study are consistent with the study of Aghamiri et al. (2013) in the field of the successes of the operations of executive management of the Red Crescent in the operation of the Azerbaijan earthquake. The first suggestion: considering the first question and hypotheses' result that role of the brand and the symbol of the Red
Crescent of the Islamic Republic is significant in the social assistance in times of accidents and crises, therefore, it is suggested: a comprehensive executive program be considered in terms of assistance in the Red Crescent Society and after disasters, the consent of injured people from the Red Crescent services be examined. ${ }^{15}$

The second suggestion: considering the second question and hypotheses' result that role of the brand and the symbol of the Red Crescent of the Islamic Republic is significant in the social works in times of accidents and crises, therefore, it is suggested: the Red Crescent Society considers special programs in terms of the psychological and social support in its programs and enhances the special teams for psycho-social support in the volunteering level. ${ }^{16}$

The third suggestion: considering the third question and hypotheses' result that the role of brand and the symbol of the Red Crescent of the Islamic Republic is significant to encourage people to assist in times of accidents and crises, which has been emphasized by Esman and Vphoff, thus, one of the important ways to welcome people from organizations and NGOs, is that they have the selection right in their organizational structure. These researchers have suggested that the Non-Governmental Organizations should consider the internal and external factors to recruit and organize popular participation, as follows:

1. The sensitivity to membership and motivate members to participate;

2. Preventing the dominance of powerful groups;

3. Encouraging and supporting the operational activities of members;

4. Organizing for an effective service delivery;

5. Organizing for communication with other local organizations and governmental organization (Saidi, 2003, pp. 32 and 33)

The forth suggestion: considering the forth question and hypotheses' result that the role of brand and the symbol of the Red Crescent of Islamic Republic is significant in successes of operations of executive management in times of accidents and crises, so it is suggested that to conduct a successful search and rescue operation, following vital seven steps always be considered:

The first step: Collecting information and assessing available facts; as the estimated number of potential victims, injured people and survivors, climatic conditions, potential hazards such as fire, collapse of high rise structures, power, water, other vital arteries outages.

The second step: Assessment of damages; this issue will be widely discussed in the section on assessment.

The third step: Identifying and providing resources; in this step, the number of personnel, tools and required equipment and the level of access are determined. 
The forth step: Prioritizing saving measures; in this step the priority of actions are determined that are required to search, rescue and relief.

The fifth step: Preparing the program; about how to deploy staff and with whom order, who is responsible for directing the operations, what are the duties of each member, how is the operation process, all are defined in the program.

The sixth step: Conducting the operations in accordance with the program;

The seventh step: Evaluating the progress of the operation.

Obviously, the information which will be obtained from each of these steps, is important for the success of the search and rescue operation. The set of these steps is called "analytic estimation 7" which is the basis for further decisions and planning in the management of search, rescue and relief. ${ }^{14}$ In order to achieve better and more comprehensive knowledge about the role of the Red Crescent in the times of crises and applying it in the crisis management, the following are recommended: It is suggested that in the subsequent studies about the Red Crescent Society, in particular, the specific role of this organization in the crisis management and considerable and effective subjects of relief on the audience, be investigated to determine the subjective preferences of people and their expectations from this search and rescue organization agency at the time of crisis. It is recommended that the agencies involved in disaster management which are among the main rings in crisis management, by collectively determining the organizational priorities in times of crisis, take an action to prepare a comprehensive study on these subjects in order to it be used as reference for subsequent researches. It is proposed that the crisis management organization, in a separate study, examines the issues of interest to people in times of crisis and through this research achieves a model, a model on which it be possible to timely and correctly inform people in times of crisis.

It is suggested that in addition to quantitative research, in later research, the qualitative methods (interviews and discourse analysis) be used to gather expert's opinions in the field of executive management and aggregate their views to benefit more from the media in times of crisis.

\section{CONCLUSION}

The influence of the name and brand of the Red Crescent Society of the Islamic Republic is moderate and significant in social assistance in social work in people's willingness to assist and in the success of the operations of executive managers in times of disasters and crises in the earthquake in Azarbayejan influence of the name and brand of the Red Crescent Society of the Islamic Republic is affective in social assistance in social work in people's willingness to assist and in the success of the operations of executive managers in times of disasters and crises.

Funding: No funding sources

Conflict of interest: None declared

Ethical approval: The study was approved by the institutional ethics committee

\section{REFERENCES}

1. Aghamiri and Colleagues. A survey on relief after the Azerbaijan earthquake. J Search Rescue Tehran. 2013;5(1):54-60.

2. Esfandiar H. Volunteers in Red Crescent. J Res Rescue Tehran. 2013;10(2):451-5.

3. Pourheydari GH, Mousavi Z, Ayoubian V, Falah F. Preparing for natural disasters and man-made disasters and actions before, during and after. In: Pourheydari GH, Mousavi Z, Ayoubian V, Falah F, eds. ICCAS Report. Tehran: Iran Crescent College of Applied Science. 2008: 12.

4. Wells William. Burnett John, Moriety Sandra. Advertising, principles and practices. In: Ghorbanlu, S, eds. First Printing Book. Tehran: Mobaleghan Publications; 2004.

5. Ghorbani Ghavidel S. Shabgu Monsef M. Effect of brand reputation on customer loyalty from the perspective of buyers of home appliances. Market Manag Summer. 2014;9(23):59-78.

6. Albert N, Merunka D. The role of brand love in consumer-brand relationships. J Cunsumer Market. 2013;3(3):258-66.

7. Ahmed PK, Rafiq M, Saad NM. IM and the mediating role of organizational competencies. Eur J Market. 2003;37(9):1221-41.

8. Al-rubaish A, A.rahim S, S.abumadini, M, Wosornu L. Academic job satisfaction questionnaire: construction and validation in Saudi Arabia. J Fam Community Med. 2011 Apr;18(1):1-7.

9. Baker T. Towards a new employment relationship model: Aligning the changing needs of individual and organization. Leadership Organ Devel J. 2009;30(3):197-223.

10. Hughes J, Rog E. (2008). Talent management: a strategy for improving employee recruitment, retention and engagement within hospitality organizations. Int $\mathbf{J}$ Contemp Hosp Manag. 2008;20(7):743-57.

11. Esmail RA, Spinelli G. Effects of brand love, personality and image on word of mouth: the case of fashion brands among young consumers. J Fashion Market Manag. 2012;16(4):386-98.

12. Keller KL. Brand mantras: rationale, criteria and examples. J Market Manag. 1999;15:43-51.

13. King C, Grace D. Internal branding: exploring the employee's perspective. J Brand Manag. 2008;15(5):358-72. 
14. Wang, Y. Collaborative destination marketing: Understanding the dynamic process. J Travel Res. 2008;47(2):151-66.

15. Wefald A, Downey R. Construct dimensionality of engagement and its relation with satisfaction. J Psychol. 2009;143(1):91-111.

16. Wilson A. The Red Crescent Society. In: Wilson A, eds. Marketing Research: an Integrated Approach. 2nd ed. Harlow: Financial Times/Prentice Hall; 2006.

Cite this article as: Halajian E, Nabavi SA, Ferdosian B. Evaluation of the role of the brand and symbol of Red Crescent Society of the Islamic Republic in the effectiveness of incidents and crises of the country (case study of East Azarbaijan). Int J Sci Rep 2015;1(1):39-44. 